\title{
The Regulatory Framework of E-Commerce
}

\author{
K. M. Anwarul Islam ${ }^{1}$ \\ ${ }^{1}$ Department of Business Administration, The Millennium University, Dhaka, Bangladesh \\ Correspondence: Department of Business Administration, The Millennium University, Dhaka, Bangladesh, \\ E-mail: ai419bankingdu@gmail.com \\ Received: October 01, 2017 \\ Accepted: October 15, 2017 \\ Online Published: October 30, 2017

\begin{abstract}
The era of globalization requires the efficient use of technologies to cope with the modern world and its features. Without technology, no nation can think about take off to development. In the business world development means economic growth and running towards its peak. This peak is attainable only after the appropriate use of unique technologies. Technology saves time and mobilizes the economy. Electronic commerce is rapidly growing as an impressive manifestation of globalization. The rapid expansion of e-commerce is a major opportunity for local and international trade development of LDCs including Bangladesh. This study concentrates only on the regulatory framework of e-commerce.
\end{abstract}

Keywords: Regulatory Framework, E-commerce.

\section{Introduction}

The Internet has opened up a new horizon for commerce, namely electronic commerce (e-commerce). The Internet, through advanced mechanisms of data transfer networks, establishes global linkages between customers and suppliers regardless of geographic location. E-commerce entails the use of the Internet in the marketing, identification, payment and delivery of goods and services. It involves order processing at company Websites and securing Electronic Fund Transfer (EFT) payment systems.

E-commerce is a way of conducting business over the Internet. Though it is a relatively new concept, it has the potential to alter the traditional form of economic activities. Already it affects such large sectors as communications, finance and retail trade and holds promises in areas such as education, health and government. The largest effects may be associated not with many of the impacts that command the most attention (i.e. customized product, elimination of middlemen) but with less visible, but potentially more pervasive, effects on routine business activities (i.e. ordering office supplies, paying bills, estimating demand).

In 1886, a telegraph operator managed to obtain a shipment of watches that had been refused by the local jeweler. Using the telegraph, he sold all the watches to fellow operators and railroad employees and then ordered more. Within a short time, he made enough money to quit his job and start his own catalog mail order business. The young man's name was Richard Sears, who founded Sears, Roebuck and Co. in 1893.

Electronic Commerce, or e-commerce, is the conduct of business by electronic means. Following this general definition, e-commerce began soon after Samuel Morse sent his first telegraph message in 1844, and it expanded across the sea when another message, containing share price information from the New York stock 
market, linked Europe and North America in 1858. By 1877, Western Union, the dominant telegraph company, moved $\$ 2.5$ million worth of transactions annually.

In the twenty-first century, e-commerce referred more specifically to transactions between businesses (B2B e-commerce) and between businesses and consumers (B2C e-commerce) through the use of computer communication, particularly the Internet. This form of electronic commerce began in 1968, when what was called Electronic Data Interchange permitted companies to carry out electronic transactions. However, it was not until 1984 that a standardized format (known as ASC X12) provided a dependable means to conduct electronic business, and it was not until 1994 that Netscape introduced a browser program whose graphical presentation significantly eased the use of computer communication for all kinds of computer activity, including e-commerce.

The business-to-business form of e-commerce fared better in 2000 and 2001. Although a faltering economy lowered expectations. B2B e-commerce evolved with the development of the Internet. One of the leading B2B firms, i2 Technologies, was founded in 1988 as a business software producer to help companies manage inventories electronically. As the Internet expanded, the role of i2 grew to include the procurement and management of all the elements required to produce finished goods. Successful in this endeavor, its revenue grew to $\$ 1.1$ billion and its profit to $\$ 108$ billion in 2000 .

By 2001, electronic commerce had not grown to levels anticipated in the late 1990s. In addition to a decline in economic growth, there remained uncertainties, particularly in relation to the consumer sector.

E-commerce has a significant impact on business costs and productivity. E-Commerce has a chance to be widely adopted due to its simple applications. Thus it has a large economic impact. It gives the opportunity for "boundary crossing" as new entrants, business models, and changes in technology erode the barriers that used to separate one industry from another. This increases competition and innovation, which are likely to boost overall economic efficiency.

\section{Regulatory Framework for E-Commerce}

Electronic commerce generates competition, revenue and profit. It also creates flows of goods and services and hence traffic. Subsequently, it can act as an incentive for investors to finance locally available infrastructures, connectivity and bandwidth. However, before this 'virtuous circle' can be initiated, the 'magic triangle' - access, trust and know-how - an essential precondition for the start-up and expansion of electronic commerce, must be firmly established between both the public and the private partners involved. This magic triangle can only be set in place if it receives the full and active support from the various stakeholders.

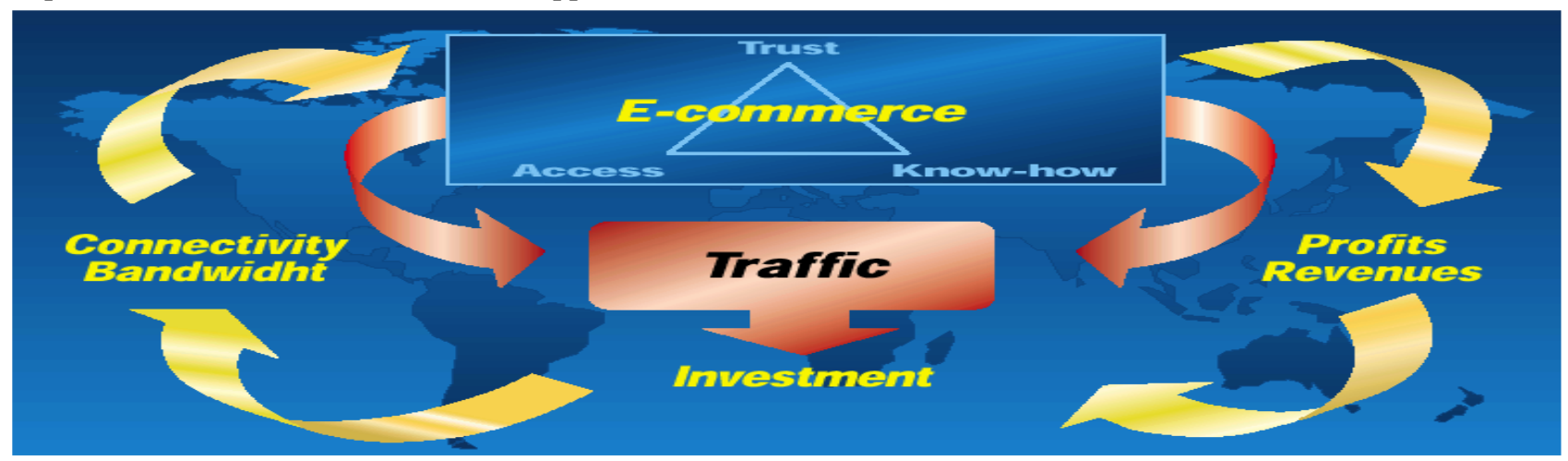

Figure 1. The Magic Triangle of E-Commerce

Source: International Telecommunications Union, Millennium, October 1999. Geneva 
Access to e-technology such as the Internet is a necessary but not a sufficient condition for the development and growth of e-commerce. The popularity of e-commerce in any economy will be dependent not only on the cost, efficiency and reliability of Internet technology but also on the supportive framework that includes legal and financial infrastructural support as well as support in the form of technical expertise (know-how)

\section{Regulatory and Legal Environment}

To keep pace with the new era of globalization, Bangladesh's legal framework must ensure that appropriate legislative, judicial and administrative processes that support the public interest and private economic rights are in place. However, not much has been done in Bangladesh towards achieving that goal. Although certain century-old laws are being updated, the only significant legislative changes made in recent years have not proved to be very effective because of weak enforcement or provisions that allow for over-regulation (e.g. the Financial Loan Courts Act; the Securities and Exchange Commission Act).

\section{Key Macro Policies}

There are two major government documents that reflect the mood of trade and investment policy directions to be pursued in the medium term. These are the Five-Year Plans and the Industrial Policy. A brief summary of these documents suggests a trend towards an increasing private sector led growth through the promotion of trade and investment.

The Foreign Private Investment (Promotion and Protection) Act of 1980 guarantees legal protection to foreign investors against nationalization and also indemnifies them against losses due to civil unrest. It also guarantees repatriation of capital and dividend and equal treatment with local investors. In comparison with the investment regimes in South Asian countries, the investment regime in Bangladesh attracted only marginal inflows although it is considered to be more open than that of India. For instance, while there are limits to foreign equity participation in India and Pakistan, there are no limits placed on foreign equity participation. However, licensing regulations are required by the private sector in energy and telecommunications, which is also applicable in other South Asian countries.

\subsection{Trade and Commerce Related Legislation}

In the area of foreign trade, the legal framework is primarily governed by three legislative Acts: The Imports and Exports (Control) Act, 1950; The Customs Act, 1969; and The Foreign Exchange (Regulation) Act, 1947. Revisions and updates of these Acts are made periodically.

The Import Policy Order (IPO) 1997-2002 exemplifies a liberalized trade regime, which accommodates Bangladesh's decision to join the WTO. Unlike earlier import policy regimes, it does not discourage the import of consumer items. The Export Policy 1997-2002 aims at promoting exports in the regional and international markets. It calls for the diversification of exports, encouraging backward linkages, simplification of procedures and developing the necessary infrastructure.

In January 2000, Bangladesh adopted the WTO Customs Valuation system. Minimum import process (called Tariff Value) was used until recently for customs valuation purposes. With the PSI system made mandatory in 1999-2000, the system of Tariff Values has been abolished. 


\begin{tabular}{|l|l|}
\hline Area & Legislation \\
\hline Custom Duties & Customs Act, 1969 \\
\hline Import Regulations & Imports and Export (Control) Act, 1950; Customs Act, \\
$1969 ;$ review, Appeal and Revision Order, 1977; \\
Importers, Exporters and Indentors (Registration) Order, \\
$1981 ;$ Licenses and Permit Fees Order, 1985
\end{tabular}

\begin{tabular}{|l|l|}
\hline Area & Legislation \\
\hline Foreign Exchange & Foreign Exchange (Regulation) Act, 1947 \\
\hline Banking Service & Banking Companies Act, 1991 \\
\hline Insurance Services & $\begin{array}{l}\text { Insurance Act, 1938; Insurance Corporations Act, 1973; } \\
\text { Insurance Rules, 1953 }\end{array}$ \\
\hline Telecommunications Services & Telegraph Act, 1887 \\
\hline Air Transport Services & Details not available from the authorities \\
\hline Maritime Transport Service & $\begin{array}{l}\text { Merchant Shipping Ordinance, 1993; Inland Shipping } \\
\text { Ordinance, 1976; Bangladesh Flag Vessel (Protection) } \\
\text { Ordinance, 1982 }\end{array}$ \\
\hline Source: World Trade Organization, 2000. Trade Policy Review Bangladesh.
\end{tabular}

Recently, there have been allegations of misrepresentation of commodities and country of origin. Adequate checks and deterrents in the form of fines and other civil and criminal charges are to be put in order to ensure that the PSI system is not compromised through cheating, collusion and graft.

\subsection{Other Related Regulations}

Other related regulations include the Intellectual Property Rights (IPR) legislation, which dates from the pre-independence era. Patents, trademarks, and copyrights are governed by: the Patents and Designs Act, 1911 and the Patents and Designs Rule, 1933; the Trade Marks Act, 1940 and the Trade Marks Rules, 1963; and the Copyright Ordinance, 1962, as amended by the Copyright (Amendment) Act, 1974, and the Copyright (Amendment) Ordinance, 1978.

The agreement on Trade-Related Intellectual Property Rights (TRIPS) provides standards for Intellectual Property Rights relating to patents, copyright and related rights, trademarks, industrial designs, and layout designs of integrated circuits, undisclosed information, and trade secrets. Bangladesh has an eleven-year transitional period (i.e. until January 2006) to meet the obligations under this agreement. The prevailing national legislation requires amendments to conform to the provisions of the agreement on TRIPS. There is also a strong need for developing administrative ability to enforce intellectual property rights. 
The Contract Law in Bangladesh is governed by the Contract act 1872. According to this Act, cross border contracts are legal. As with the Evidence Act, a physical signature is necessary to make a contract valid. However, with regard to communication regarding the contract, letters by post and telegrams are acceptable in the eyes of the law. Legislation that legalizes digital certificates, electronic contracts, etc should also be enacted. Two acts play an important role in dispute settlement cases -- the Arbitration Act 1940 and the Money Loan Court Act 1990. The Arbitration Act governs the settlement of any disputes arising from business transactions. The primary aim of this Act is to attempt to resolve the differences of the two parties without having to resort to a Court of Law.

The Money Loan Court (ArthaRinAdalat) is an independent judicial body established under the Money Loan Court Act 1990 and the Money Loan Court Regulation 1990 to recover public money loaned to individuals through public sector financial institutions. The judges for these courts are selected from among the Sub-Ordinate Judges by the government in collaboration with the Supreme Court and administratively it performs directly under the Supreme Court. According to the Act, Money Loan Courts are supposed to be established in every district in Bangladesh, with the provision that if necessary more than one Court may be established in a single district. However, so far only a few Courts have been established.

Two Articles in the Constitution in Bangladesh -- Article 15 and Article 18 - state some broad principles regarding consumer protection. Article 18 specifically includes raising the level of nutrition and improvement of public health among the state's primary duties. Article 15 can be interpreted as making the provision of basic necessities a fundamental responsibility of the state. The Penal Code 1860 is one of the oldest existing statutes in Bangladesh.

Certain provisions in this code have direct bearing on consumer rights; some of which have been broadened into separate legislative acts. However, apart from these very broad principles, specific legislation is hard to identify. The meager legislation that does exist is scattered through other acts that are only indirectly related to consumer protection

\section{Acts and Laws Related To Consumer Protection}

1. Control of Essential Commodities Act 1956

2. Pure Food Ordinance 1959

3. Price and Distribution of Essential Commodities Ordinance 1970

4. Bangladesh Drugs Control Ordinance 1982

5. Breast Milk Substitute (Regulation of Marketing) Ordinance 1984

6. Tobacco Goods Marketing (Control) Act 1988

7. Penal Code 1860

8. Special Powers Act 1974

9. Dangerous Drugs Act 1930

10. Trade Mark Act 1940

11. Standards of Weights and Measures Ordinance 1982

Source: Rahman, Mizanur, 1994. Consumer Protection Law and the Swedish Approach.

\section{Telecommunications: An Integral Part of E-Commerce}

Access, pricing, and the quality of Internet services are critically dependent on the status and performance of the telecommunications sector. The telecommunication sector of Bangladesh is characterized by poor level of 
penetration (0.4 telephone for every 100 persons, Graph 1), high cost to access, $\$ 341$ connection fees for each telephone, one of the highest in the world, and a lengthy waiting period -- average waiting period for a new telephone connection varies from three months to ten years.

In recent years the government has demonstrated the need for increased participation of the private sector in the production and delivery of telecommunication services. Although the Bangladesh Telegraph and Telephone Board (BTTB) continues to be a monopoly in providing basic telephone connections, the private sectors involvement in cellular phones and as Internet Service Providers (ISP) have been allowed. Private sector participation in improving and widening the telecommunication infrastructural facilities has also been accepted.

The major body directly affecting the legal and institutional framework of Internet development is the Bangladesh Telegraph and Telephone Board (BTTB). BTTB was the regulator until the Ministry of Posts and Telecommunications (MOPT) took over that function in 1995. The Telegraph Act of 1885 in tandem with the Wireless Act of 1933 had been the governing tool until the National Telecommunications Policy (NTP98) was enacted in 1998.

NTP98 may be considered the first step toward reforming the country's telecom sector. In tandem with the macro trade policy of the 1990s of trade liberalization and increased private sector participation, NTP98 aims at major reforms in the telecommunication sector.

With the objective of improving the quality and availability of services, NTP98 emphasizes infusion of technology (e.g. digitalization), greater access across the country, and a competitive framework. To bring about the transformation and to ensure that the objectives of NTP98 are implemented, NTP98 suggests establishment of an independent regulator, Bangladesh Telecommunications Regulatory Commission (BTRC). However, BTRC has yet to become operational.

\section{Independence of the Regulator}

Like in any other sector, independence of the regulator is the essence of telecom and IT success in Bangladesh. The World Bank has been assisting MOPT to establish an independent telecom regulator. Matheson Ormsby Prentice Solicitor, a Dublin-based Irish law firm, was hired to prepare the amended Telecommunications Act in this regard. They finalized the draft in 1998 with the provision of five full-time Commissioners. The President of Bangladesh, in consultation with the Speaker, the Chief Justice, the Prime Minister and the Leader of the Opposition would appoint the Commissioners for five years. Their appointments may be renewed for another five years or for a shorter term. The President would also appoint a Chairman from the five Commissioners, who would be the chief executive of the Commission. The rank of the Chairman would be equivalent to a Minister and the Commissioners' status would be similar to a Deputy Minister.

They also revoked the President's active role in appointing the Commissioners. Besides, ministerial status of the Chairman and Commissioners of the Commission was also abolished. They would be appointed by the government and reporting to the Minister of MOPT. Their proposed monthly remuneration of Taka 100,000 has also been reduced to Taka 17,000 (approximately \$300). Lately the World Bank not only declined funding this US\$ 12 million project, but also demanded back US\$ 1.5 million, an amount that has so far been disbursed to kick off this project. A stalemate situation has been prevailing in this regard. NIP98, similar to policy prescriptions offered in other sectors, faces bureaucratic and political challenges to develop a well-functioning telecommunication sector that would be conducive to telecommunication improvements in general and Internet services in particular. The road to establishing a strong and independent regulatory body has been a difficult one. Identification and recruitment of qualified senior managers, called Commissioners, have experienced 
resistance in terms of compensation packages that may be offered.

Four years prior to NTP98, private Internet Service Providers (ISPs) launched the Internet. Albeit NTP98 acknowledges the critical need for easy and affordable access to Internet services, BTTB's pricing and regulatory strategy on ISPs are restrictive. For instance, until February 2000, the ISPs were not allowed to choose the Very Small Aperture Terminal (VSAT) carriers other than the ones recommended by the government (BTTB).

In addition to paying the standard tariff to the VSAT operators or capacity re-sellers, the ISPs were mandated to pay royalty to BTTB. Presently ISPs pay an annual royalty of $\$ 3,200$ to MOPT. Also, they are currently allowed to independently deal with the VSAT carriers. The fees charged and the earlier restrictions on the selection of VSAT carriers contributed to higher pricing for Internet consumers, thereby delaying exposure to this technology to many.

The government's undeclared embargo on utilizing this huge idle network has been hindering the growth of the Internet in Bangladesh. It grossly contradicts the overall objective of NTP98. However, the government's consent on re-selling Grameen Phone's infrastructure would not be sufficient for the growth of the Internet (e-commerce) unless accessing the customers' premises is guaranteed. BTTB controls the entire outside plant (OSP) or cabling network, which is exclusively copper-based. Hence, bandwidth limitation remains as a chronic ailment at the customers' end. Customers seldom get more than 4 kbps due to the extremely poor OSP of BTTB.

While precluding the usage of Grameen Phone's optical fiber network, BTTB has rolled out Digital Subscribers Line (DSL) services in the name of Digital Data Network (DDN). DDN's prohibitively expensive pricing has failed to make it popular. The government is yet to allow the private sector's intervention in enhancing the bandwidth of BTTB's access network.

One possible means to overcome the prevailing bandwidth constraints is to introduce Multichannel, Multi-point Distribution System (MMDS) or Local Multi-channel Distribution System (LMDS) solutions. Radio spectrum is still being allocated in accordance with the Wireless Act of 1933. Administering the Frequency Allocation Board with BTTB officials and heading this highly technical body with a bureaucrat inherently diminishes the required proactive role of this body. Provision of unlicensed spectrum is still prohibited due to the required regulatory guidelines. NTP98, however, as a policy objective, recognizes freedom for exchange of information. MMDS and LMDS can be a viable alternative in an extremely poor teledensity country such as Bangladesh.

BTTB's decision to itself offer Internet services since 1999 has caused concerns among the private providers. They claim that there is uneven competition since the state telecommunication is exempted from paying necessary fees and royalties to the government. Since BTTB is also the Post, Telegraph and Telephone (PTT) monopoly, it neither requires any additional investment nor faces any delay on obtaining telephone line for its Internet venture. Participation of BTTB enhances the number of sellers of ISP service thereby providing greater choice to buyers. However, uneven competition can discourage private sector participation and investment, thereby reducing competition.

Despite having four incumbent mobile operators, the MOPT has allowed BTTB to launch cordless mobile telephony with phenomenal concessions in license fees. MOPT has also announced that BTTB would be launching another cellular mobile services soon. Similar to the ISP market, BTTB's unfair advantage may crowd out private sector participation. 


\section{VOIP Application: An Illlustration}

Thousands of Bangladeshi workers live in Singapore. They make a considerable number of phone calls to friends and families back home. The existing 120 voice circuits between Bangladesh and Singapore gets congested and the rate of unsuccessful calls start mounting in Singapore. Since the Bangladesh bound traffic is much higher, the Singapore Telecom (SingTel) ends up losing substantial revenue.

In May 1999, SingTel proposed a win-win solution to BTTB. SingTel would establish a VoIP link between the two countries at its own cost followed by reducing 50 percent call charges, as they would be transported over the Internet. This would mean great savings for the Bangladeshi workers in Singapore and the congestion in the satellite circuits would be significantly reduced. It means, more Bangladesh bound calls from Singapore and BTTB making more money from the international revenue sharing agreement with SingTel.

BTTB's monopoly over the long distance and international voice traffic, however, remains protected by NTP98 until 2000 and 2010 respectively. This has been a consistent impediment for the growth of e-commerce. Voice over Internet Protocol (VoIP) has proven to be a very important catalyst in promoting e-commerce.

Several policy reforms aimed at boosting the IT sector, eventually contributing to ecommerce development, have been accomplished. The decision to cease BTTB's role as a broker between the ISPs and the VSAT operators in early 2000 was overwhelmingly appreciated by the private sector. It reduced the potential of bureaucratic delays and uncertainties. The government's recent decision to award an operating license for 300,000 telephones in Dhaka will meet much of the unmet demand. Discussions between BTTB and Singapore Telecom (SingTel) on laying a submarine cable between Bangladesh and Singapore are progressing well. SingTel is expected to invest $\$ 140$ million in this project.

\section{Financing and Banking Mechanism}

There are three types of export financing in Bangladesh: pre-shipment financing in local currency by commercial banks; pre-shipment financing in foreign currency by commercial banks through the Export Development Fund (EDF); and back-to-back letter of credit (L/C) facilities.

Exporters can access credit in local currency from private and nationalized commercial banks at a concessional rate determined by the Bangladesh Bank (BB). The Interest Rate Policy introduced in 1992, which liberalized interest rate ceilings for all categories of lending except to export, agriculture, and small and cottage industries, permitted individual banks to differentiate interest rates charged to individual borrowers. The interest rate bands for exports have been set in the range of 8 percent to 10 percent since 1994-95.

Exporters can obtain export credit for up to 90 percent of the value of their irrevocable $\mathrm{L} / \mathrm{C}$ or sales agreement for a maximum period of 180 days. The Export Development Fund (EDF), administered by the Bangladesh Bank (BB), provides pre-shipment financing for imports of necessary raw materials, spare parts, and packaging materials for exporters of nontraditional items. Like other export credits, the time limit for repayment is usually 180 days, extendable to 270 days in exceptional cases.

\subsection{Letter of Credit Mechanism}

In Bangladesh, $\mathrm{L} / \mathrm{C}$ is the predominant legal method of international transactions. Lack of real time information on the transactions and goods clearance with the Central Bank is the primary reason behind the existence of an orthodox payment mechanism such as the L/C. Inherent delay of paying the seller by L/C inevitably elevates the price up to 15 percent.

Exporters of certain products may open "back-to-back" L/Cs for the required imports of raw materials 
against their export L/C. These include ready-made garments, specialized textiles, household linen, hosiery, toys, luggage and fashion goods, electronic items, and leather goods.

Under the inland back-to-back L/C system, local suppliers of raw materials to export industries can also obtain advantageous financing. A number of studies have reported that lack of access to trade financing, caused by a weak commercial banking system and foreign exchange scarcity, has constrained Bangladesh's export expansion. In the mid-1990s, whereas exports accounted for almost one third of industrial output, it received only 9 percent of total industrial financing. The insistence by commercial banks on the use of $\mathrm{L} / \mathrm{Cs}$ for export financing, as well as the existence of interest rate ceilings on export loans, have negatively affected exporters' access to local credit. On the other hand, indirect exporters are forced to give inter-firm credit for their sales of indirect export items to direct exporters because they do not have the option of sight or advance payments from direct exporters; this seems to be inconsistent with the government's policy of promoting backward linkages. Moreover, it is reported that the users of the back-to-back L/C system may end up paying the extra cost of importing inputs, estimated at 7-8 percent higher than under the normal system.

The prevailing L/C system, albeit quite successful, is being considered for replacement in some countries. A Contract System (CS) would be introduced which would adhere to safe guards and documentation necessary under the banking regulations. CS is expected to be faster and cheaper to implement, as it would minimize the role of the commercial banks, thereby avoiding certain bank charges and other related fees. Banks will be used primarily for transfer of funds, which will be made electronically within 48 hours of the shipment.

To make the CS more effective, the means of e-commerce e.g., the web version of necessary documents (original contract and supporting documents), encryption, digital signature, digital identification need to be introduced. The prevailing L/C system can be difficult to implement through e-commerce because of its unavoidable complexities.

\subsection{Banking Mechanism}

Automation and EFT in the Financial Sector: In Bangladesh, electronic fund transfer is at an early stage and used on a very limited scale. Electronic banking, which is highly dependent on the application of IT, has been pioneered by the foreign commercial banks. The local banks are yet to be fully automated. Most local banks use computers on a stand-alone basis. The extent of computerization in the local banks is limited to database management and electronic communication (through e-mails) only. A few foreign commercial banks and local banks are offering on-line banking facilities in the form of Automated Teller Machines (ATM) and local credit cards. Only one multi-national bank is now practicing on-line fund transfer between its branches, and two other local banks are supposed to introduce it within 2001.Also, the banks now offering ATM facilities have formed a common ATM pool.

The development of electronic banking within the country as well as outside the country is saddled with various infrastructural, institutional and regulatory constraints. A selected list of these constraints is provided below:

- Lack of network infrastructure of commercial banks

- Absence of a centralized clearing system of the Central Bank

- Absence of EFT legislation

- Exchange controls are too restrictive to promote e-commerce

- Absence of a need based business plan for on-line banking

- Inadequate qualified manpower to set up and maintain the network 
Convertibility of the Taka: The Taka (the currency of Bangladesh) has been convertible for current account transactions. Consequently, earnings from the trading account are freely convertible into foreign exchange for the importation of goods.

Retention Quota: Exporters are at present allowed to retain 40 percent of their f.o.b. export earnings in foreign currency accounts denominated in U. S. Dollars, Pound Sterling, Deutsche Marks, Japanese Yen or the Euro.

International Credit Cards: Restriction on issuance of international credit cards prevails although local credit cards introduced by multi-national banks have become popular in Bangladesh. The Central Bank's main concern against issuance of international credit cards is flight of capital from Bangladesh. However, the Central Bank has no objection on issuance of a generally accepted credit card, which will be honored by all commercial banks for local use only. Regrettably, the network for this type of credit card has yet to be established.

Illegal Cross-border Payment: As businessmen are allowed to carry a restricted amount of foreign currency legally, many of them make foreign payments through the illegal - but extensively used - system of "Hundi". The Hundi system is based on a basic barter principle. In this system, an individual or even a business in one country can instantaneously transfer funds to another country without the inevitable hassle that characterizes official fund transfer channels. The Hundi works through middlemen who ensure that the amounts required by the individual or the business reach the recipient almost instantaneously. When the borrower is assured (through telephone calls or other means) that the recipient is in possession of the loan, he/it then pays an equivalent amount in the local currency to the local counterpart of the middleman. The popularity of this system increases whenever the official rate of international currencies varies significantly from the market rate. The Hundi system deprives the government of the much sought foreign exchange reserves.

\section{Human Capital}

Successful application of e-commerce demands not only availability of technology and infrastructural facilities but also a skilled manpower that can appreciate and apply it. Bangladesh lacks skilled manpower and knowledgeable managers in the IT sector. Computers are primarily used for word processing, making presentations, e-mails in selected formal sector business establishments. However, the communication is constrained by the quality of verbal and written communication skills in English, which is mediocre at best, even among university graduates. If Bangladesh aims to interact closely with the international markets and seeks growth through exports, improved communication and computer skills among various segments of the society are imperative.

A good understanding of the current benefits and future opportunities of e-commerce is essential for the advancement of e-commerce. The lack of knowledge among public officials about the Internet and its potential, and their application in e-commerce, significantly handicaps policy reforms in this sector. In the private sector, viable IT sector projects fail to obtain financing due to the lack of understanding of the investors.

\section{Governance and Policy Implementation Constraints}

Regulatory intrusiveness is a way of economic life in Bangladesh. Ageing laws on patents, trademarks and copyrights; post and telegraphs; land ownership and transfer; and employment have yet to be brought into alignment with modern practices and requirements (The World Bank, 1996).

In addition to this, Bangladesh has an intractable problem of poor governance. This has been manifested in the form of continued involvement of politicians and public officials, often in collusion with the 
private sector, in undermining the rule of law. As a consequence, institutions continue to remain weak and legal and regulatory reforms are difficult to implement. Rent seeking activities galore, discouraging competition and promotion of efficiency.

The problem of poor governance in conjunction with ambiguously drafted, inconsistently applied, and often contradictory regulations makes the whole process of dealing with the government an experience that most businessmen prefer to avoid. The lack of confidence in secure and flexible business transactions is widespread among the business community.

Conducting business at the Chittagong port (the main port of Bangladesh) is comparatively more expensive than anywhere else in the region. The handling charge for a 20 feet container is $\$ 640$ in Chittagong as compared to $\$ 220$ for Colombo, $\$ 360$ for Bangkok and \$216 for Singapore. One of the main reasons for such abnormally high costs for the port in Bangladesh has frequent strikes (hartaals) and arbitrary work stoppages by the trade unions.

\section{The Hidden Cost of Service}

Customs clearance and procedures continues to be saddled with delays and allegations of informal payments. The introduction of Pre-shipment Inspection (PSI) agents, and the Green Channel are steps in the right direction in promoting speedy movement of goods.

However, the government's reliance on Customs as a major source of tax revenue and private sector's attempts to find ingenious means to forego taxes (at times in collusion with Custom officials) demands further modernization and improved monitoring systems of the Custom authorities.

Corporate taxes are high and burdensome, because of the hassle involved in dealing with tax authorities - resulting in widespread tax evasion. Modest coverage and weak enforcement make corporate taxation a minor contributor to the treasury. In addition, the tax system is not client friendly, appeal procedures are lengthy, and definitions of deductible business expenses are strict and nontransparent.

For developing economies like Bangladesh, Foreign Direct Investment (FDI) is believed to be critical for much needed capital in infrastructural development, infusion of technology and for accessing overseas markets.

Acceptance and successful application of e-commerce would enhance the business environment, sending signals to foreign investors that it is becoming easier to do business in Bangladesh.

\section{Conclusion}

A key reason why e-commerce, especially the business-to-business segment, is growing so quickly is its significant impact on costs associated with inventories, sales execution, procurement, intangibles like banking, and distribution costs. If these reductions become pervasive, e-commerce has the potential to be the application that ushers in the large productivity gains. Achieving these gains is therefore contingent on a number of factors, including access to e-commerce systems and the needed skills. However, what is unique about ecommerce over the Internet and the efficiency gains is that it promises the premium placed on openness. To reap the potential cost savings. 


\section{References}

Bangladesh e-Commerce Week. (2013). Bangladesh Bank and Bangladesh Association of Software and Information Services (BA-SIS) are jointly going to organize a special awareness and promotional campaign through organizing.

\section{Copyrights}

Copyright for this article is retained by the author(s), with first publication rights granted to the journal. 